\title{
ANALISIS HUBUNGAN EFISIENSI DAN KINERJA PERBANKAN SYARIAH DI INDONESIA DENGAN METODE DATA ENVELOPMENT ANALYSIS (DEA) DAN METODE CAPITAL, ASSET, MANAGEMENT, EARNING, LIQUIDITY, SENSITIVITY TO MARKET RISK (CAMELS)
}

\author{
Rifqi Amrulloh \\ Sekolah Tinggi Ilmu Ekonomi Pancasetia Banjarmasin \\ Jl. A Yani Km. 5,5 Banjarmasin, Kalimantan Selatan \\ e-mail : rifq_juve@yahoo.com
}

\begin{abstract}
The purpose of this study was to determine the efficiency level and the performance of sharia banking in Indonesia and the correlation between efficiency and performance of sharia banking in Indonesia. The type of this study was descriptive research. The object of this study was financial statements of 10 sharia banks in Indonesia. The data analysis methods used were data envelopment analysis (DEA), CAMELS ratio analysis of, and product moment correlation analysis. The result of this study showed that based on DEA analysis there were four sharia banks that showed the efficiency level reaching $100 \%$ or in the efficient level. On CAMELS ratio analysis showed that sharia banks were in good financial ratio condition. However, the value of ratios showed a fluctuation from year to year in the research period. Correlation analysis between CAMELS and DEA showed that there was no financial ratio that gave a result in line with DEA analysis because the significance level of correlation coefficient showed a value that was not significant statistically.
\end{abstract}

Keywords: efficiency, performance, sharia banking

Abstrak: Tujuan penelitian ini adalah untuk mengetahui tingkat efisiensi dan kinerja perbankan syariah di Indonesia serta korelasi antara efisiensi dan kinerja perbankan syariah di Indonesia. Jenis penelitian ini adalah penelitian deskriptif. Objek penelitian ini adalah laporan keuangan 10 bank syariah di Indonesia. Metode analisis data yang digunakan adalah data envelopment analysis (DEA), CAMELS ratio analysis, dan product moment correlation analysis. Hasil penelitian menunjukkan bahwa berdasarkan analisis DEA terdapat empat bank syariah yang menunjukkan tingkat efisiensi mencapai $100 \%$ atau pada tingkat yang efisien. Dalam analisis rasio CAMELS, menunjukkan bahwa bank syariah berada dalam kondisi rasio keuangan yang baik. Namun, nilai rasio menunjukkan fluktuasi dari tahun ke tahun dalam periode penelitian. Analisis korelasi antara CAMELS dan DEA menunjukkan bahwa tidak ada rasio keuangan yang memberikan hasil sesuai dengan analisis DEA karena tingkat signifikansi koefisien korelasi menunjukkan nilai yang tidak signifikan secara statistik.

Kata Kunci: efisiensi, kinerja, bank syariah

\section{Latar Belakang}

Eksistensi lembaga keuangan, khususnya sektor perbankan menempati posisi sangat strategis dalam menjembatani kebutuhan modal kerja dan investasi di sektor riil dan pemilikan dana. Dengan demikian, fungsi utama sektor perbankan dalam infra-stuktur kebijakan makroekonomi diarahkan dalam konteks bagaimana menjadikan uang efektif untuk meningkatkan nilai tambah ekonomi (how to make money effective and efficient to increase economic value). 
Dalam upaya mencapai tujuan pembangunan yang dilakukan, baik kebijakan fiskal maupun kebijakan moneter yang dilakukan oleh pemerintah yaitu di bidang perbankan. Bank sebagai badan usaha yang berorientasi pada pencapaian keuntungan (profit oriented) dan pemerintah sebagai agent of diploma yang memberikan kesempatan bagi pihak-pihak yang berkeinginan menghimpun sebuah usaha yang berawal dari masyarakat dan melepaskan kembali ke masyarakat yang berupa pembiayaan atau pembiayaan. Adapun jenis bank yang berkembang di Indonesia dewasa ini ada dua jenis bank yaitu bank syariah dan bank konvensional. Bank syariah adalah salah satu bank umum yang berkembang di Indonesia yang ikut memberikan dukungan dalam pembangunan ekonomi di Indonesia melalui pembiayaan kepada nasabah dan memberi fasilitas jasa-jasa perbankan untuk menunjang aktifitas ekonomi rakyat. Namun, sistem yang ditawarkan ke-dua bank tersebut dalam prinsipnya berbeda. Bank konvensional lebih bersifat profit oriented, sedangkan bank syariah lebih bersifat kemitraan, yaitu cara-cara bagi profit dan risiko dengan tujuan mewujudkan kegiatan ekonomi yang lebih adil dan lebih transparan. Dengan berkembangnya bank syariah dewasa ini, diharapkan mampu membunuh wabah penyakit negative spirit (keuntungan minus) dari dunia perbankan dan diharapkan menghapus sampai ke akar-akarnya.

Hal ini diperkuat oleh desakan sebagian warga muslim yang menganggap bahwa bunga bank itu riba atau masalah mutasyabihat (masalah yang masih samar). Dari permasalahan ini timbul gagasan untuk segera mendirikan sebuah lembaga keuangan yang berbasis syariah atau bank syariah. Bank syariah adalah bank umum yang mulai dikaji oleh MUI pada tahun 1980. Akan tetapi, realisasinya baru pada tahun 1992 dan bank syariah yang pertama kali lahir di Indonesia adalah bank muamalat Indonesia. Hal ini juga didukung oleh undang-undang No. 10 tahun 1998 tentang diperbolehkannya beroperasinya bank syariah di Indonesia yang menawarkan produk-produk pembiayaan murobahah atau jual beli barang dengan harga asal dan ditambah dengan margin keuntungan yang telah disepakati bersama. Pembelian ini memudahkan para nasabah tidak membayar secara kontan.

Selama krisis moneter (1997-1998) bank syariah dapat bertahan dan dapat menunjukkan kinerja yang relatif lebih baik dibandingkan lembaga perbankan konvensional. Itu dapat dilihat dari relatif lebih rendahnya penyaluran pembiayaan yang bermasalah (nonperforming loan, tahun 2000 sebesar 12,96\% dan tahun 2001 sebesar 4,04\%, sumber: Bank Indonesia) pada bank syariah dan tidak terjadinya negative spread dalam kegiatan operasionalnya. Dengan filosofi utamanya, kemitraan dan kebersamaan dalam maupun risk, bank syariah terbukti prospektif untuk berkembang di tanah air.

Perkembangan perbankan syariah menunjukkan laju yang signifikan. Hal ini ditunjukkan dengan terjadinya peningkatan nilai aset perbankan syariah yang telah mencapai $\mathrm{Rp}$ 4,78 triliun. Sementara dana pihak ketiga mencapai Rp 3,4 triliun, dengan pembiayaan yang diberikan oleh bank syariah telah mencapai Rp 3,86 triliun. Hal ini menunjukkan terjadinya peningkatan untuk jumlah aset sebesar $18,22 \%$, dana pihak ketiga sebesar $16,66 \%$, dan pembiayaan yang disalurkan $17,73 \%$ dibandingkan terhadap posisi masing-masing di akhir tahun 2002 (Deputi BI Maulana, Republika 25/6/2003).

Salah satu tantangan yang kini banyak dihadapi dan paling berat adalah banyaknya tudingan yang mengatakan bank syariah hanya sekedar perbankan konvensional yang ditambah label syariah. Tantangan lainnya adalah bagaimana menonjolkan ciri khas perbankan syariah, yakni bank yang secara langsung membangun sektor riil dengan prinsip keadilan. Selain itu, dari aspek eksternal, sektor perbankan syariah memiliki tantangan dari sisi pemahaman sebagian masyarakat yang masih rendah terhadap operasional bank syariah. Mereka secara sederhana beranggapan bahwa dengan tidak dijalankannya sistem bunga, bank syariah tidak akan memperoleh pendapatan. Konsekuensinya adalah bank syariah akan sulit untuk bertahan hidup.

Penelitian dilakukan oleh Bank Indonesia bekerjasama dengan beberapa lembaga penelitian yang berusaha untuk memetakan potensi pengembangan bank syariah yang 
didasarkan pada analisis potensi ekonomi dan pola sikap/preferensi dari pelaku ekonomi dan jasa bank syariah. Selain itu juga untuk mempelajari karakteristik dan perilaku dari kelompok masyarakat pengguna dan calon pengguna jasa perbankan syariah sebagai dasar penetapan strategi sosialisasi dan pemasaran bagi bank-bank syariah. Penelitian tersebut dilakukan di seluruh pulau Jawa dengan mengambil sampel di beberapa kabupaten dan kotamadya, yang dibagi menjadi tiga wilayah penelitian: Jawa Barat, Jawa Tengah/DIY dan Jawa Timur.

Dari penelitian tersebut terungkap bahwa $95 \%$ responden berpendapat bahwa sistem perbankan penting dan dibutuhkan dalam mendukung kelancaran transaksi ekonomi. Penelitian tersebut juga mengungkapkan bahwa kesan umum yang ditangkap oleh masyarakat tentang bank syariah adalah (1) bank syariah indentik dengan bank dengan sistem bagi hasil, (2) bank syariah adalah bank yang islami. Namun berdasar-kan survey yang dilakukan di wilayah Jawa Barat $8,1 \%$ responden yang menyatakan bahwa bank syariah secara ekslusif hanya khusus untuk umat Islam. Selain itu, juga terungkap bahwa pengetahuan masyarakat tentang sistem perbankan syariah relatif tinggi. Meskipun demikian, pemahaman mengenai keunikan produk/jasa bank syariah secara umum masih rendah.

Saat ini sebagian besar dari mereka hanya melihat bahwa nilai tambah bank syariah adalah lebih halal dan selamat, lebih menjanjikan untuk kebaikan akhirat, dan juga lebih berorientasi pada menolong antar sesama dibandingkan dengan bank konvensional. Hal tersebut memang benar, namun bank syariah memiliki keuntungan duniawi karena produk-produknya tidak kalah bersaing dengan bank-bank konvensional dan juga bagi hasil yang ditawarkan tidak kalah menguntungkan dibandingkan dengan bunga.

Dengan masih rendahnya pemahaman masyarakat akan pemahaman Islam apalagi masalah perbankan bahkan perekonomian secara lebih luas maka perbankan syariah harus terus berkembang dan memperbaiki kinerjanya. Dengan pesatnya pertumbuhan yang ditandai semakin banyaknya bank konvensional yang akhirnya mendirikan unit- unit syariah. Hal ini membuktikan bahwa bank syariah memang mempunyai kompetensi yang tinggi. Perbankan syariah akan semakin tinggi lagi pertumbuhannya apabila tingkat efisiensi dapat dilakukan sehingga keberlangsungan bank syariah dapat terus berlanjut.

Kini bank syariah tumbuh dan berkembang pesat. Apalagi dengan hadirnya sejumlah bank umum syariah (BUS) semakin memantapkan posisi perbankan syariah di Indonesia. Bank syariah hadir dengan mengkombinasikan idealisme usaha dan nilai-nilai rohani dalam operasionalisasinya. Harmoni antara idealisme usaha dan nilainilai rohani tersebut, menjadi salah satu keunggulan bank syariah sebagai solusi dan kiprah baru perbankan Indonesia.

Namun permasalahan yang dihadapi oleh bank syariah salah satunya adalah dalam hal perbaikan kinerja. Perbaikan kinerja dalam perbankan syariah ini nampaknya juga didukung oleh adanya efisiensi dalam pengelolaannya. Terdapat dua konsep efisiensi yang sering dipergunakan dalam ekonomi, yaitu: efisiensi produktif dan efisiensi alokatif (Mahi, 2000). Efisiensi produktif adalah efisiensi yang tercapai karena organisasi suatu proses produksi berjalan dengan baik dan optimal. Artinya, untuk menghasilkan output harus didukung oleh pengelolaan kegiatan yang seoptimal mungkin. Sementara itu, efisiensi alokatif terjadi karena sumber daya dapat dilakukan secara optimal.

Untuk dapat mencapai efisiensi dalam produksi, sangat penting bagi daerah untuk mengelola faktor produksi seoptimal mungkin. Dapat diartikan bahwa kombinasi input yang dipergunakan memiliki biaya produksi yang serendah mungkin. Produksi dibentuk oleh kombinasi faktor produksi (input) modal, tenaga kerja, sumber alam serta teknologi. Kunci dari penigkatan output adalah tercapainya produktivitas yang tinggi, yang harus dimiliki oleh setiap faktor produksi bersangkutan. Pengukuran kinerja secara lebih cermat dan menyeluruh sulit dilakukan disebabkan oleh variasinya tujuan (output) sumber daya yang digunakan (input), perbedaan skala kegiatan ekonomi perusahaan dan tidak terdapatnya referensi tentang kinerja yang dapat digunakan secara obyektif. 
Penelitian ini akan mencakup pengukuran kinerja perbankan, yang dikonsentrasikan perbankan syariah dengan sampel penelitian pada sepuluh bank syariah, yaitu Bank Muamalat, Bank Syariah Mandiri, Bank Syariah Mega, Bank BNI Syariah, Bank BRI Syariah, Bank Danamon Syariah, Bank Bukopin Syariah, Bank Niaga Syariah, Bank Permata Syariah, dan Bank Tabungan Negara Syariah.

Berdasarkan latar belakang sebagaimana disebutkan sebelumnya, maka rumusan masalah yang diajukan adalah sebagai berikut ini.

1. Bagaimana tingkat efisiensi relatif perbankan syariah di Indonesia?

2. Bagaimana kinerja perbankan syariah di Indonesia?

3. Bagaimana hubungan efisiensi relatif dengan kinerja perbankan syariah di Indonesia?

\section{Kajian Literatur}

Walaupun telah banyak literatur yang membahas tentang efisiensi pada perbankan Amerika Serikat dan Eropa pada tahun-tahun belakangan ini, namun karya-karya pada perbankan Islam masihlah sangat terbatas. Umumnya, studi pada efisiensi bank Islam berfokus pada isu teoritis dan karya empiris lebih banyak mendasarkan pada analisis statistik deskriptif dan bukannya pada estimasi statistik yang lebih maju.

Efisiensi maupun produktivitas, keduanya dapat digunakan sebagai bahan untuk mengukur kinerja suatu unit kegiatan ekonomi, meskipun secara prinsip kedua pengukuran tersebut berbeda. Konsep efisiensi lebih berkaitan dengan seberapa jauh suatu proses mengkonsumsi masukan untuk menghasilkan keluaran tertentu, sementara konsep produktivitas berkaitan dengan seberapa jauh suatu proses menghasilkan keluaran dengan mengkonsumsi masukan tertentu (Mulyadi, 2000: 437). Efisiensi dan produktivitas merupakan suatu ukuran tentang seberapa efisien suatu proses mengkonsumsi masukan dan seberapa produktif suatu proses menghasilkan keluaran. Efisiensi merupakan rasio antara keluaran dengan masukan suatu proses, dengan fokus perhatian pada konsumsi masukan. Produktivitas merupakan rasio antara masukan de- ngan keluaran, dengan fokus perha-tian pada keluaran yang dihasilkan oleh suatu proses.

Efisiensi ekonomi terdiri dari efisiensi teknis (technical effisiency) dan efisiensi alokasi (allocative effisiency). Efisiensi teknis merupakan kombinasi antara kapasitas dan kemampuan unit kegiatan ekonomi untuk memproduksi sampai tingkat output maksimum dari input-input dan teknologi yang tetap. Efisiensi alokasi merupakan kemampuan dan kesediaan unit ekonomi untuk beroperasi pada tingkat nilai produk marjinal (marginal value product) sama dengan biaya marjinal (marginal cost). Ada tiga kegunaan mengukur efisiensi. Pertama, sebagai tolak ukur untuk memperoleh efisiensi relatif, mempermudah memperbandingkan antara unit ekonomi satu dengan lainnya. Kedua, apabila terdapat variasi tingkat efisiensi dari beberapa unit ekonomi yang ada maka dapat dilakukan penelitian untuk menjawab faktor-faktor apa yang menentukan perbedaan tingkat efisiensi. Ketiga, informasi mengenai efisiensi memiliki implikasi kebijakan karena manajer dapat menentukan kebijakan perusahaan secara tepat.

Efisiensi teknis sebenarnya mencerminkan seberapa tinggi tingkat teknologi dalam proses produksi. Pada umumnya teknologi yang dipergunakan dalam proses produksi dapat digambarkan dengan mempergunakan kurva isokuan (isoquand), fungsi produksi (production function), fungsi biaya (cost function), dan fungsi keuntungan (profit function).

Komaryatin (2006) mengatakan efisiensi perbankan dapat dianalisis dengan efisiensi skala (efficiency scale), efisiensi dalam cakupan (effisiency scope), efisiensi teknis (technical efficiency), dan efisiensi lokasi (allocative efficiency). Bank dikatakan mencapai efisiensi dalam skala ketika perbankan bersangkutan mampu beroperasi dalam skala hasil yang konstan (constant return to scale), sedangkan efisiensi cakupan tercapai ketika perbankan mampu beroperasi pada diversifikasi lokasi. Efisiensi alokasi tercapai ketika bank mampu menentukan berbagai output yang mampu memaksimalkan keuntungan, sedangkan efisiensi teknis merupakan hubungan antara input dengan output dalam suatu proses produksi. Suatu proses produksi 
dikatakan efisien jika pada penggunaan input sejumlah tertentu dapat dihasilkan output yang maksimal, atau untuk menghasilkan output sejumlah tertentu digunakan input yang paling minimal. Lebih jauh dijelaskan bahwa perbankan dikatakan efisien secara teknis apabila menghasilkan output maksimal dengan sumber daya tertentu atau memproduksi sejumlah tertentu output menggunakan input yang minimal.

Menurut Ozcan (2008), pengukuran efisiensi dapat dilakukan dengan berbagai metode, yaitu analisis rasio, least-squares regression (LSR), total factor productivity (TFP), stochastic frontier analysis (SFA), dan data envelopment analysis (DEA).

Pendekatan analisis rasio merupakan metode penilaian efisiensi yang paling sederhana karena menghasilkan informasi dari hubungan antara satu input dan satu output. Oleh karena itu, efisiensi didefinisikan sebagai banyaknya unit output per unit input. Manajemen seringkali menggunakan kombinasi lebih dari satu rasio untuk mengukur efisiensi. Hal ini dapat dimungkinkan jika terdapat lebih dari satu variabel input dan/ atau output.

Metode pengukuran efisiensi yang kedua adalah regresi kuadrat terkecil (leastsquared regression/LSR). Metode ini adalah metode parametrik yang dalam penghitungannya berasumsi bahwa semua entitas adalah efisien. Selain dapat mengakomodasi lebih dari satu input dan output, LSR juga dapat menghitung noise dengan menggunakan error term (e). LSR mempunyai beberapa keuntungan, yaitu LSR dapat digunakan untuk mengukur perubahan teknis jika menggunakan data periodik (time series) dan ekonomi skala dapat dihitung. Walaupun demikian, LSR juga memiliki beberapa kelemahan. Pertama, LSR mengukur berdasarkan kecenderungan atau nilai rata-rata (averaging techniques). Kedua, LSR tidak mampu mengidentifikasi unit yang tidak efisien. Ketiga, LSR mensyaratkan fungsi produksi yang didasarkan perhitungan parametrik. Berdasarkan penjelasan tersebut, analisis regresi tidak mampu memprediksi unit yang paling efisien. Oleh karena itu, perlu dicari metodologi lain yang mampu menjelaskan pengukuran efisiensi dengan lebih tepat.
Metode yang ketiga adalah total factor productivity (TFP). Metode ini dipakai untuk mengatasi kelemahan analisis rasio yang tidak mampu menghitung efisiensi dari lebih dari satu input/output. TFP diukur dengan menggunakan angka indeks, yang dapat mengukur perubahan harga dan kuantitas sepanjang waktu. Selain itu, TFP juga mengukur perbandingan dan perbedaan antarentitas.

Metode yang keempat adalah stochastic frontier analysis (SFA). Metode SFA juga sebuah metode parametrik. SFA mengasumsikan bahwa semua entitas adalah tidak efisien. SFA juga menghitung adanya noise. SFA dapat digunakan untuk pengujian hipotesis. SFA juga dapat digunakan untuk mengukur efisiensi teknis, skala ekonomi, efisiensi alokatif, perubahan teknis, dan perubahan TFP (jika berupa data panel). SFA juga dapat digunakan untuk mengukur data panel dan cross-section. SFA juga mempunyai kelemahan, misalnya SFA mensyaratkan spesifikasi bentuk fungsi dan bentuk distribusi unit yang tidak efisien. Dengan penggunaan informasi harga, kesalahan pengukuran tambahan mungkin dimasukkan dalam hasil. Unit yang tidak efisien merupakan hasil perhitungan efisiensi teknis dan alokatif. Kedua sumber ketidakefisienan ini tidak dapat dipisahkan.

Metode yang kelima adalah data envelopment analysis (DEA). DEA mengasumsikan bahwa tidak semua entitas adalah efisien. DEA mampu menganalisis lebih dari satu input dan/atau output dengan menggunakan model program linier yang menghasilkan nilai efisiensi tunggal untuk setiap penelitian.

Penelitian ini menggunakan metode DEA untuk mengukur efisiensi dikarenakan beberapa keunggulan yang dimiliki oleh metode DEA dibandingkan dengan metode lainnya. Dibandingkan metode yang lain. Purwantoro (2003) menyebutkan keunggulan DEA adalah:

1. bisa mengolah banyak input dan output;

2. tidak membutuhkan asumsi adanya hubungan fungsional antara variabel input dengan output;

3. DMU dibandingkan secara langsung dengan sesamanya (homogen); dan

4. input dan output dapat memiliki satuan pengukuran yang berbeda. 
Selain menggunakan metode DEA, penelitian ini juga menggunakan metode CAMEL yang merupakan perhitungan rasiorasio keuangan perbankan untuk menilai tingkat kesehatan perbankan.

Menurut Undang-Undang No. 10 tahun 1998 bank syariah adalah bank umum yang melaksanakan usaha berdasarkan prinsip syariah yang dalam kegiatannya memberikan jasa dalam lalu lintas pembayaran. Prinsip syariah adalah aturan perjanjian berdasarkan hukum Islam antara bank dengan pihak lain untuk penyimpanan dana dan atau pembiayaan kegiatan usaha atau kegiatan lainnya yang sesuai dengan syariah.

Prinsip yang dijalankan dalam melaksanakan operasional bank syariah adalah sebagai berikut ini.

1. Prinsip keadilan, tercermin dari penerapan imbalan atas dasar bagi hasil dan pengambilan margin keuntungan yang telah disepakati oleh bank dan nasabah.

2. Prinsip kesederajatan, bank syariah menempatkan nasabah penyimpan dana, nasabah pengguana dana, maupun bank pada kedudukan yang sama dan sederajat. Hal ini tercermin dalam hak, kewajiban, risiko, dan keuntungan yang berimbang di antara nasabah penyimpan dana, nasabah pengguna dana, maupun pihak bank.

3. Prinsip ketenteraman, produk-produk bank syariah telah sesuai dengan prinsip dan kaidah muamalah Islam, antara lain: tidak ada unsur riba dan menerapkan zakat harta. Dengan demikian, nasabah merasakan ketenteraman lahir dan batin.

Bank syariah pada hakekatnya dikelola berdasarkan konsep berikut ini.

1. Islam memandang harta sebagai titipan atau amanah Allah SWT sehingga cara memperoleh, mengelola, dan memanfaatkannya harus sesuai dengan ajaran Islam.

2. Bank syariah mendorong nasabah untuk mengelola hartanya sesuai ajaran Islam.

3. Bank syariah menempatkan akhlaqul karimah baik nasabah maupun pengelola bank sebagai sikap yang mendasari hubungan antara nasabah dan bank.

4. Adanya kesamaan ikatan emosional yang kuat didasarkan prinsip keadilan, prinsip kesederajatan, dan prinsip ketenteraman antara pemegang saham, pengelola bank, dan nasabah atas jalannya usaha bank syariah.

5. Prinsip bagi hasil yaitu sebagai berikut ini. a. Penentuan besarnya risiko, bagi hasil dibuat pada waktu akad dengan berpedoman pada kemungkinan untung dan rugi.

b. Besarnya nisbah bagi hasil berdasarkan jumlah keuntungan yang diperoleh.

c. Jumlah bagi hasil meningkat sesuai dengan peningkatan jumlah pendapatan.

d. Tidak ada yang meragukan keuntungan bagi hasil.

e. Bagi hasil tergantung pada keuntungan proyek yang dijalankan. Jika proyek itu tidak mendatangkan keuntungan, maka kerugian itu akan ditanggung bersama oleh kedua belah pihak.

Dibandingkan dengan bank syariah, pengelolaan bank konvensional didasari oleh konsep sebagai berikut ini.

1. Pada bank konvensional terjadi konflik kepentingan diantara tiga pihak, yaitu pihak yang menginginkan bunga yang tinggi, serta kepentingan pemegang saham yaitu mengoptimalkan interest difference. Sementara itu, kepentingan debitor adalah memperoleh tingkat bunga yang rendah. Dalam hal ini bank konvensional berfungsi sebagai perantara saja.

2. Tidak adanya ikatan emosional antara pemegang saham, pengelola bank, dan nasabah karena masing-masing pihak memiliki keinginan yang bertolak belakang.

3. Sistem bunga yaitu sebagai berikut ini.

a. Penentuan suku bunga dibuat pada waktu akad dengan menekankan pada keuntungan pihak bank.

b. Besarnya persentase berdasarkan pada jumlah modal yang dipinjamkan.

c. Jumlah pembayaran bunga tetap.

d. Adanya bunga diragukan kehalalannya.

Prinsip-prinsip dasar produk bank syariah yang diaplikasikan dalam kegiatan menghimpun dana (produk pendanaan), antara lain sebagai berikut ini.

1. Wadiah (depository), yaitu titipan dari satu pihak kepada pihak lain, baik individu 
maupun badan hukum, yang harus dijaga dan dikembalikan setiap saat bila pemilik menghendaki.

2. Mudharabah muthlaqah (general investment), yaitu erjasama antara dua pihak di mana pihak pertama menyediakan modal dan memberikan kewenangan penuh kepada pihak kedua dalam menentukan jenis dan tempat investasi, sedangkan keuntungan dan kerugian dibagi menurut kesepakatan bersama.

3. Mudharabah muqayyadah, yaitu kerjasama antara dua pihak dimana pihak pertama menyediakan modal dan memberikan kewenangan terbatas kepada pihak kedua dalam menentukan jenis dan tempat investasi, sedangkan keuntungan dan kerugian dibagi menurut kesepakatan di muka.

Prinsip-prinsip dasar produk syariah yang diaplikasikan dalam kegiatan penyaluran dana atau produk pembiayaan adalah sebagai berikut ini.

1. Murabahah (deferred payment sale), yaitu suatu perjanjian yang disepakati antar bank syariah dengan nasabah di mana bank menyediakan pembiayaan untuk pembelian bahan baku/modal kerja lainnya yang dibutuhkan nasabah yang akan dibayar kembali oleh nasabah sebesar harga jual (harga beli bank + margin keuntungan) pada waktu yang telah ditentukan.

2. Mudharabah (trust financing, trust investment), yaitu kerjasama antara dua pihak di mana pihak pertama menyediakan modal sedangkan pihak kedua mengelola dana di mana keuntungan dan kerugian dibagi bersama menurut kesepakatan dimuka.

3. Musyarakah (partnership, project financing participation), yaitu Perjanjian pembiayaan antara bank syariah dengan nasabah yang membutuhkan pembiayaan, di mana bank dan nasabah secara bersama membiayai suatu usaha/proyek yang juga dikelola secara bersama atas prinsip bagi hasil sesuai dengan penyertaan di mana keuntungan dan kerugian dibagi sesuai kesepakatan di muka.

4. Salam (in-front payment sale), yaitu pembiayaan jual beli di mana pembeli memberikan uang terlebih dahulu terhadap barang yang dibeli yang telah disebutkan spesifikasinya dengan pengantaran kemudian.

5. Istishna (purchase by order or manufacture), yaitu pembiayaan jual beli yang dilakukan bank dan nasabah dimana penjual (pihak bank) membuat barang yang dipesan oleh nasabah.

6. Ijarah (operational lease), yaitu perjanjian sewa yang memberikan kepada penyewa untuk memanfaatkan barang yang akan disewa dengan imbalan uang sewa sesuai dengan persetujuan dan setelah masa sewanya berakhir maka barang dikembalikan kepada pemilik, namun penyewa juga dapat memiliki barang yang disewa dengan pilihan pemindahan kepemilikan atas barang yang disewa dari pihak bank oleh pihak lain.

Adapun prinsip produk-produk syariah dalam penyelenggaraan jasa-jasa perbankan adalah sebagai berikut ini.

1. Kafalah (guaranty), yaitu akad pemberian garansi/jaminan oleh pihak bank kepada nasabah untuk menjamin pelaksanaan proyek dan pemenuhan kewajiban tertentu oleh pihak yang dijamin.

2. Wakalah (deputyship), yaitu akad perwakilan antara kedua belah pihak (bank dan nasabah) di mana nasabah memberikan kuasa kepada bank untuk mewakili dirinya melakukan pekerjaan/jasa tertentu.

3. Hawalah (transfer service), yaitu akad pemindahan piutang nasabah kepada bank untuk membantu nasabah mendapatkan modal tunai agar dapat melanjutkan produksinya dan bank mendapat imbalan atas jasa pemindahan piutang tersebut.

4. Ar-rahn (mortgage), yaitu menahan salah satu harta milik nasabah yang memiliki nilai ekonomis sebagai jaminan atas pinjaman yang diterimanya.

5. Al-qardh (soft and benevolent loan), yaitu emberian harta kepada nasabah yang dapat ditagih atau diminta kembali atau dengan kata lain meminjamkan tanpa mengharapkan imbalan.

Dalam penelitian ini pengukuran tingkat efisiensi ditekankan pada pengukuran efisiensi secara teknis. Efisiensi teknis menjelaskan efisiensi suatu DMU dalam meng- 
ubah input menjadi output. Pengukuran efisiensi teknis dapat dilakukan diberbagai tingkat kegiatan, baik sektor swasta maupun sektor publik.

Menurut Ramanathan (2003), DEA adalah teknik berbasis program linier untuk mengukur efisiensi unit organisasi yang dinamakan decision making units (DMU), yaitu organisasi-organisasi atau entitas-entitas yang akan diukur efisiensinya secara relative terhadap sekelompok entitas lainnya yang homogen. Homogen berarti input dan output dari DMU yang dievaluasi harus sama/sejenis. DMU dapat berupa entitas komersial maupun publik, seperti bank komersial atau pemerintah, sekolah swasta atau negeri, rumah sakit, dan sebagainya.

Pada sektor publik, mengukur efisiensi teknis ini banyak berhubungan dengan penyediaan jasa layanan kepada masyarakat. Pengukuran efisiensi ini berkaitan erat dengan kinerja yang dilakukan pada unit kerja yang ada di pemerintah daerah, rumah sakit, unit layanan masyarakat seperti Puskesmas juga pada kantor Samsat.

Terdapat dua metode yang lazim digunakan untuk mengukur efisiensi, yaitu analisis rasio parsial dan analisis regresi berganda (Pause, 2000). Masih menurut Pause (2000: $3,5)$ hasil dari analisis rasio parsial sulit untuk menentukan suatu unit ekonomi yang paling efisien, dengan menggunakan input dan output dalam jumlah dan jenis yang sama. Karena masing-masing unit ekonomi memiliki kemampuan dalam mengkonversikan satu jenis input tertentu ke dalam satu jenis output tertentu. Hasil dari analisis regresi berganda mempunyai kelemahan jika suatu unit ekonomi menghasilkan dua atau lebih output, maka harus digabungkan menjadi satu; dan di sinilah letak kelemahan tersebut karena tidak semua jenis output dapat digabungkan menjadi satu.

DEA dapat mengatasi keterbatasan yang dimiliki oleh analisis rasio parsial dan analisis regresi berganda. DEA dirancang khusus untuk mengukur efisiensi relatif suatu Unit kegiatan ekonomi (UKE) dengan menggunakan banyak input dan menghasilkan banyak output, di mana penggabungan banyak output itu tidak mungkin dilakukan. Efisiensi relatif suatu UKE adalah efisiensi suatu UKE dibandingkan dengan UKE lainnya dalam sekelompok UKE yang saling diperbanding yang menggunakan jenis input dan output yang sama. Efisiensi relatif ini didefinisikan sebagai rasio dari total output tertimbang dibagi dengan total input tertimbang. Inti dari DEA adalah menentukan bobot atau timbangan untuk setiap input dan output UKE. Bobot tersebut bersifat (1) universal dan (2) tidak bernilai negatif; artinya setiap UKE dalam sampel harus dapat menggunakan seperangkat bobot yang sama untuk mengevaluasi rasionya (total weighted output/total weighted input) dan rasio yang dihasilkan tidak boleh lebih dari 1 .

DEA berasumsi bahwa setiap UKE memilih bobot yang memaksimumkan rasio efisiensinya karena setiap UKE menggunakan kombinasi input yang berbeda untuk menghasilkan kombinasi output yang berbeda pula. Dengan demikian setiap UKE akan memilih seperangkat bobot yang mencerminkan keragaman. Secara umum UKE akan menetapkan bobot yang tinggi untuk input yang penggunaannya sedikit dan untuk output yang dapat diproduksi dalam jumlah yang banyak. Bobot-bobot tersebut bukan merupakan nilai ekonomis dari input dan output-nya melainkan sebagai penentu untuk memaksimumkan efisiensi dari suatu UKE.

Beberapa nilai manajerial dari DEA, pertama, menghasilkan efisiensi untuk setiap UKE, relatif terhadap UKE yang lain dalam sampel, sehingga bagi UKE yang paling tidak efisien dapat diberikan perhatian yang besar untuk perbaikannya. Kedua, bagi suatu UKE yang kurang efisien (efisiensi $<100 \%$ ) terdapat angka penggandanya yang dapat digunakan untuk menyusun strategi perbaikan. Ketiga, dalam DEA disedia matriks efisiensi silang yang dapat membantu untuk mengenali UKE yang efisien tetapi dengan menggunakan kombinasi input dan menghasilkan kombinasi output yang sangat berbeda dengan UKE yang lain. UKE itu sendiri biasanya disebut maverick (menyimpang, unik).

DEA untuk suatu UKE dapat diformulasikan sebagai program linier fraksional, yang solusinya dapat diperoleh jika model tersebut ditransformasikan ke dalam program linier dengan bobot dari input dan output UKE tersebut sebagai variabel keputusan. 
Metode simpleks dapat digunakan ke dalam program linier. DEA yang lengkap memerlukan penyelesaian program linier bagi setiap UKE. Hasilnya adalah seperangkat bobot untuk suatu UKE dan angka efisiensi relatifnya (Pause, 2000:7).

Model DEA untuk suatu unit kegiatan dapat diformulasikan ke dalam sebuah program linier fraksional dengan variabel keputusannya diambil dari input dan output dari UKE yang bersangkutan. Sebagai contoh terdapat sejumlah n UKE yang akan dibandingkan tingkat efisiensinya. Masing-masing UKE menggunakan sejumlah $\mathrm{m}$ input dan akan menghasilkan sejumlah s output. Dinyatakan $\mathrm{Xij}>0$ adalah jumlah input $\mathrm{i}$ yang digunakan UKE $\mathrm{j}$ dan Yrj $>0$ adalah jumlah output $\mathrm{r}$ yang digunakan UKE j. Variabel keputusan dari kasus ini adalah bobot yang harus diberikan pada setiap input dan output oleh UKE k. Kemudian vik adalah bobot pada input $\mathrm{i}$ dimana $\mathrm{i}=1,2, \ldots, \mathrm{m}$ dari UKE $\mathrm{k}$ dan urk adalah bobot pada output $\mathrm{r}$ dimana $\mathrm{r}$ $=1,2, \ldots, \mathrm{s}$ dari UKE $\mathrm{k}$. Formulasi program linier dibuat sebanyak 1 untuk tiap-tiap UKE.

Fungsi tujuan dari program linier fraksional untuk UKE $\mathrm{k}$ adalah sebagai berikut (Silkman, 1986:46).

$$
\mathrm{h}_{\mathrm{s}}=\frac{\sum_{\mathrm{i}=1}^{\mathrm{m}} \mathrm{u}_{\mathrm{is}} \mathrm{y}_{\mathrm{is}}}{\sum_{\mathrm{i}=1}^{\mathrm{n}} \mathrm{v}_{\mathrm{js}} \mathrm{x}_{\mathrm{js}}}
$$

Di mana :

$\mathrm{h}_{\mathrm{s}} \quad=$ efisiensi teknis bank $\mathrm{s}$

$\mathrm{u}_{\text {is }}=$ bobot output $\mathrm{i}$ yang dihasilkan oleh bank $\mathrm{s}$

$\mathrm{y}_{\mathrm{is}}=$ jumlah output $\mathrm{i}$, yang diproduksi oleh bank s

$\mathrm{v}_{\mathrm{js}}=$ bobot input $\mathrm{j}$ yang digunakan oleh bank $\mathrm{s}$

$\mathrm{x}_{\mathrm{js}}=$ jumlah input $\mathrm{j}$, yang diberikan oleh bank $\mathrm{s}$

Dalam hal ini, termasuk menemukan nilai untuk $\mathrm{u}$ dan $\mathrm{v}$, sebagai sebuah pengukuran efisiensi $h_{s}$ yang maksimal. Dengan tujuan untuk kendala bahwa semua ukuran efisiensi haruslah kurang dari atau sama dengan satu, salah satu masalah dengan formulasi atau rumusan rasio ini adalah bahwa ia memiliki sejumlah solusi yang tidak terbatas (infinite). Untuk menghindari hal ini, maka kita dapat menentukan kendala sebagai berikut ini. $\frac{\sum_{\mathrm{i}=1}^{\mathrm{m}} \mathrm{u}_{\mathrm{is}} \mathrm{y}_{\mathrm{is}}}{\sum_{\mathrm{i}=1}^{\mathrm{n}} \mathrm{v}_{\mathrm{js}} \mathrm{x}_{\mathrm{js}}} \leq 1$ untuk $\mathrm{r}=1,2, \ldots, \mathrm{N}$

$\mathrm{u}_{\mathrm{i}} \operatorname{dan} \mathrm{V}_{\mathrm{j}} \geq 0$

Di mana:

$\mathrm{N}=$ jumlah bank dalam sampel

Pertidaksamaan pertama menunjukkan adanya efisiensi rasio untuk perusahaan lain tidak lebih dari 1, sementara pertidaksamaan kedua berbobot positi f. Angka rasio akan bervariasi antara 0 sampai dengan 1. Bank dikatakan efisien apabila memiliki angka rasio mendekati 1 atau 100 persen. Sebaliknya, jika mendekati 0 menunjukkan efisiensi bank yang semakin rendah. Pada DEA, setiap bank dapat menentukan pembobotnya masing-masing dan menjamin bahwa pembobot yang dipilih akan menghasilkan ukuran kinerja yang terbaik. Berapa bagian program linier ditransformasikan sebagai berikut ini.

Maksimasi $h_{s}=\sum_{i=1}^{m} u_{i} y_{i s}$

Kendala $\sum_{\mathrm{i}=1}^{\mathrm{m}} \mathrm{u}_{\mathrm{r}} \mathrm{y}_{\mathrm{ir}}-\sum_{\mathrm{j}=1}^{\mathrm{m}} \mathrm{v}_{\mathrm{j}} \mathrm{x}_{\mathrm{j}} \mathrm{r} \leq \mathrm{o}, \mathrm{r}=1, \ldots N$

$\sum_{j=1}^{m} v_{j} x_{j s}=1$ dan $u_{i}$ dan $v_{j} \geq 0$

Efisiensi pada masing-masing bank dihitung menggunakan programasi linier dengan memaksimumkan jumlah output yang dibobot dari bank s. Kendala jumlah input yang dibobot harus sama dengan satu untuk semua bank, yaitu jumlah output yang dikurangi jumlah input yang dibobot harus kurang atau sama dengan 0 . Hal ini berarti semua bank akan berada atau di bawah referensi kinerja frontier yang merupakan garis 1 lurus yang memotong sumbu origin.

Dalam hal pengukuran tingkat eifiensi, teknik DEA ini memiliki beberapa keunggulan dan keterbatasan (PAUSE, 2000:24-25). Keunggulan tersebut antara lain:

1. input dan output yang digunakan sebagai variabel-variabel keputusan dapat diguna- 
kan dalam jumlah yang banyak dan tidak diperlukan definisi penting terhadapnya;

2. perbedaan satuan dari masing-masing variabel yang tidak perlu dispesifikasikan ke dalam satuan dasar ukur yang sama;

3. tidak tergantung pada variabel harga yang sulit ditentukan jika dilaksanakan pada sektor publik;

4. tiap-tiap input dan output dalam suatu UKE yang diperbandingkan mampu diidentifikasikan baik sumber maupun tingkat inefisiensinya; dan

5. dapat menentukan dan mengidentifikasikan sejumlah UKE yang dinilai efisien yang dapat digunakan sebagi referensi bagi UKE yang dinilai tidak efisien.

Di sisi lain beberapa keterbatasan dari metode DEA sebagai berikut ini.

1. Efisiensi yang dihasilkan DEA bersifat teknis dan berlaku hanya pada sekelompok obyek penelitian yang dibandingkan saja.

2. DEA mensyaratkan semua input dan output harus spesifik dan dapat diukur. Kesalahan dalam memasukkan variabel input dan output yang valid akan memberikan hasil yang bias.

3. Dalam DEA diasumsikan bahwa setiap unit input dan output identik dengan unit lain dalam tipe yang sama. Metode DEA membutuhkan programasi linier yang kompleks.

4. Bobot input dan output yang dihasilkan DEA tidak dapat ditafsirkan dalam nilai ekonomi, meskipun koefisien tersebut memiliki formulasi matematika yang sama.

5. Jika metode DEA ini digunakan untuk mengukur tingkat efisiensi relatif dengan jumlah sampel yang kecil maka metode ini akan sangat sensitif terhadap perbedaan antara jumlah UKE yang diteliti dan jumlah variabel input dan output yang diperhitungkan.

Analisa rasio CAMELS yaitu suatu analisis keuangan bank dan alat pengukuran kinerja bank yang ditetapkan oleh Bank Indonesia untuk mengetahui tentang tingkat kesehatan bank yang bersangkutan dari berbagai aspek yang berpengaruh terhadap kondisi dan perkembangan suatu bank dengan me- nilai faktor-faktor penilaian tingkat kesehatan bank (Kasmir, 2000:52).

Berikut ini adalah perincian dari setiap variable yang akan dianalisis dalam analisis rasio CAMELS yaitu sebagai berikut ini.

1. Modal (capital), yaitu penilaian didasarkan kepada capital atau struktur permodalan dengan metode CAR (capital adequancy ratio) yaitu dengan membandingkan modal terhadap aktiva tertimbang menurut resiko (ATMR).

2. Aset (asset), yaitu penilaian didasarkan pada kualitas aktiva yang dimiliki bank. Rasio yang diukur yaitu rasio aset produktif dan rasio penyisihan penghapusan aset produktif.

3. Manajemen (management), yaitu penilaian didasarkan pada manajemen permodalan, aset, rentabilitas, likuiditas, dan umum.

4. Rentabilitas (earning), yaitu kemampuan bank dalam meningkatkan laba dan efisiensi usaha yang dicapai. Penilaian dalam unsur ini yaitu rasio laba terhadap total aset (return on asset), rasio beban operasional terhadap pendapatan operasional (BOPO)

5. Likuiditas (liquidity), yaitu jumlah kewajiban bersih call money terhadap aktiva lancar dan rasio antara kredit terhadap dana yang diterima oleh bank.

6. Sensitivitas terhadap risiko pasar (sensitivity to market risk), dimaksudkan untuk menilai kemampuan keuangan bank dalam mengantisipasi perubahan risiko pasar yang disebabkan oleh pergerakan nilai tukar. Penilaian sensitivitas atas risiko pasar dilakukan dengan menilai besarnya kelebihan modal yang digunakan untuk menutup risiko bank dibandingkan dengan besarnya risiko kerugian yang timbul dari pengaruh perubahan risiko pasar.

Tolak ukur untuk menentukan tingkat kesehatan suatu bank setelah dilakukan penilaian terhadap masing-masing variabel, yaitu dengan menentukan hasil penilaian yang digolongkan menjadi peringkat komposit kesehatan bank. Peringkat komposit adalah peringkat akhir hasil penilaian tingkat kesehatan bank. 
Tingkat efisiensi yang dicapai merupakan cermin dari kualitas kinerja yang baik. Pada dasarnya pengukuran kinerja sebuah lembaga keuangan hampir sama. Penilaian tingkat kesehatan dan produktivitas sebuah bank, asuransi dan lembaga keuangan bukan bank (LKBB) dilakukan berdasarkan pada ketentuan peraturan perundang-undangan yang berlaku (Komaryatin, 2006).

DEA merupakan prosedur yang dirancang khusus untuk mengukur nilai efisiensi yang menggunakan banyak input dan banyak output, di mana penggabungan input dan output tersebut tidak dapat dilakukan. Skor efisiensi DEA relatif tergantung pada tingkat efisiensi dari unit-unit bank syariah lain dalam sampel. DEA mampu memberikan rekomendasi faktor-faktor apa saja yang harus dilakukan perubahan untuk mencapai efisiensi.

Kinerja keuangan bank merupakan gambaran kondisi keuangan bank pada suatu periode tertentu baik mencakup aspek penghimpunan dana maupun penyaluran dananya. Kinerja menunjukkan sesuatu yang berhubungan dengan kekuatan serta kelemahan suatu perusahaan. Kekuatan tersebut dipahami agar dapat dimanfaatkan dan kelemahan pun harus diketahui agar dapat dilakukan langkah-langkah perbaikan.

Kinerja perusahaan dapat diukur dengan menganalisa dan mengevaluasi laporan keuangan. Informasi posisi keuangan dan kinerja keuangan di masa lalu seringkali digunakan sebagai dasar untuk memprediksi posisi keuangan dan kinerja di masa depan dan hal-hal lain yang langsung menarik perhatian pemakai seperti pembayaran dividen, upah, pergerakan harga sekuritas dan kemampuan perusahaan untuk memenuhi komitmennya ketika jatuh tempo. Salah satu pengukuran yang digunakan dalam penelitian ini adalah dengan analisis CAMELS.

Dengan mendasarkan pada hasil perhitungan baik pada efisiensi maupun kinerja, maka dapat pula dilakukan analisis hubungan di antara keduanya. Ini didasarkan pada asumsi bahwa bank yang efisien akan mendorong pada peningkatan kinerjanya. Dengan demikian, peningkatan efisiensi perbankan syariah yang diperoleh dengan perhitungan DEA diperkirakan juga akan berhubungan dengan peningkatan pada kinerja perbankan yang dihitung dengan menggunakan analisis CAMELS. Demikian pula sebaliknya, penurunan efisiensi perbankan syariah yang diperoleh dengan perhitungan DEA diperkirakan akan berhubungan dengan penurunan pada kinerja perbankan yang dihitung dengan menggunakan analisis CAMELS.

Berdasarkan pada penjelasan itulah, maka dapat diduga bahwa ada hubungan yang signifikan antara efisiensi perbankan syariah yang diperoleh dengan perhitungan DEA dengan kinerja perbankan yang dihitung dengan menggunakan analisis CAMELS. Dengan demikian, dapat dirumuskan hipotesis sebagai berikut:

H1 : Ada hubungan yang positif antara efisiensi perbankan syariah yang diperoleh dengan perhitunga DEA dengan kinerja perbankan yang dihitung dengan menggunakan analisis CAMELS."

\section{Metode Penelitian}

Jenis penelitian yang digunakan dalam penelitian ini adalah penelitian deskriptif (descriptive research) yaitu metode dalam meneliti status kelompok manusia, suatu objek, suatu set kondisi, suatu sistem pemikiran atau kelas peristiwa pada masa sekarang. Tujuannya adalah membuat deskripsi, gambaran atau lukisan secara sistematis, faktual dan akurat mengenai fakta-fakta serta hubungan antar fenomena yang diselidiki (Nazir. 1999: $63)$.

Terdapat beberapa metode dalam metode deskriptif. Dalam penelitian ini metode yang diterapkan adalah teknik survei yaitu penelitian yang dilakukan dengan mengambil sampel dari suatu populasi dan mengadakan kuesioner sebagai pengumpulan data yang pokok (Singarimbun, 1995:3). Tujuannya yaitu untuk mengumpulkan data serta mempelajari gejala atau fenomena sosial dengan jalan meneliti variabel-variabel penelitian yang dilaksanakan.

Obyek penelitian ini adalah pada laporan keuangan 10 bank syariah yang ada di Indonesia, yaitu Bank Muamalat, Bank Syariah Mandiri, Bank Syariah Mega, Bank BNI Syariah, Bank BRI Syariah, Bank Danamon Syariah, Bank Bukopin Syariah, Bank Niaga Syariah, Bank Permata Syariah, dan Bank Tabungan Negara Syariah untuk mengukur 
dan membandingkan kinerja pada perusahaan.

Aspek yang diteliti dalam penelitian terdiri atas dua variabel yaitu variabel input dan variabel output. Penentuan variabel-variabel ini mendasarkan pada penelitian yang dilakukan oleh Sufian dan Majid (2008), di mana variabel tersebut adalah sebagai berikut:

1. variabel output, terdiri dari: total loan dan investment; dan

2. variabel input, terdiri dari: total deposit, labor, dan total assets.

Untuk analisis CAMELS, variabel yang digunakan meliputi capital adequacy ratio (CAR), kualitas aktiva produktif (KAP), return on assets (ROA), rasio beban operasional terhadap pendapatan operasional (BOPO), net profit margin (NPM), dan loan to deposit ratio (LDR).

Jenis dan sumber data yang dibutuhkan untuk menunjang penelitian ini adalah data sekunder, yaitu data yang telah ada dan tersusun secara sistematis serta merupakan hasil penelitan atau rangkuman dari dokumen-dokumen perusahaan.

Untuk mengumpulkan data mengenai objek penelitian digunakan metode pengumpulan data melalui penelitian kepustakaan. Hal ini dilakukan dengan cara mencari data sekunder yang diperoleh dari berbagai sumber, baik dari literatur, artikel, data perusahaan, dan lain-lain yang dianggap relevan dengan penelitian. Tujuan penelitian kepustakaan ini adalah untuk memperoleh data teoritis untuk membangun landasan teori yang kuat guna mendukung penelitian ini.

Metode analisis data dilakukan dengan model DEA dengan tujuan untuk mengukur efisiensi masing-masing bank. Bank yang memiliki skor DEA sama dengan satu (DEA $=1$ ) adalah yang efisien, sedangkan yang kurang dari satu (DEA < 1) dikatakan kurang efisien atau tingkat efisiensi yang rendah.

Untuk pengukuran kinerja bank, DEA merupakan transportasi program linier dengan asumsi yaitu keluaran constant return to scale akan menunjukkan bahwa kinerja terbaik bank memiliki angka rasio 1 atau 100\%. Bank dengan kinerja 100\% hanya terjadi apabila tidak ada unit lain atau kombina- si bank yang menggunakan input sama akan menghasilkan output minimal sama dengan jumlah output yang diterima bank yang berkinerja $100 \%$.

Adapun urut-urutan analisis dengan menggunakan program DEAP adalah sebagai berikut:

1. menentukan variabel input dan output dalam analisis DEA;

2. menjalankan program DEAP;

3. memasukkan data melalui program DEAP;

4. Menentukan cara perhitungan struktur bobot yang terdiri dari constant return to scale (CRS), banker, chames and cooper (BCC) atau variable returns to scale (VRS);

5. menjalankan perhitungan;

6. menampilkan output hasil perhitungan;

7. melakukan analisis; dan

8. menarik kesimpulan.

Alat analisis kedua yang digunakan adalah teknik analisa CAMELS. Adapun penilaian dari masing-masing aspek CAMELS meliputi :

1. Capital (modal), penilaian didasarkan pada capital atau struktur permodalan dengan metode CAR (capital adequancy ratio) yaitu dengan membandingkan modal terhadap aktiva tertimbang menurut resiko (ATMR). Adapun rumus yang digunakan adalah sebagai berikut:

$$
\mathrm{CAR}=\frac{\text { total modal }}{\text { aktiva tertimbang menurut risiko }} \times 100 \%
$$

2. Asset (aset), penilaian didasarkan pada kualitas aktiva yang dimiliki bank. Rasio yang diukur ada dua macam yaitu rasio aktiva produktif dan rasio penyisihan penghapusan aktiva produktif. Aset suatu bank akan dinilai berdasarkan kualitas aktiva produktif KAP yang diklasifikasikan adalah aktiva produktif, baik yang sudah maupun yang mengandung potensi tidak memberikan penghasilan atau menimbulkan kerugian yang besarnya ditetapkan sebagai berikut:

a. 25\% dari kredit yang digolongkan dalam perhatian khusus (DPK);

b. $50 \%$ dari kredit yang digolongkan kurang lancar (KL); 
c. $75 \%$ dari kredit yang digolongkan diragukan (D); dan

d. $100 \%$ dari kredit yang digolongkan macet (M)

$\mathrm{KAP}=\frac{\text { Aktiva Produktif yang diklasifikasikan }}{\text { aktiva produktif }} \times 100 \%$

3. Earning (rentabilitas), adalah kemampuan bank dalam meningkatkan laba dan efisiensi usaha yang dicapai. Penilaian dalam unsur ini yaitu rasio laba terhadap total aset (return on asset), rasio beban operasional terhadap pendapatan operasional (BOPO) dan net profit margin (NPM).

$$
\begin{aligned}
& \mathrm{ROA}=\frac{\text { laba sebelum pajak }}{\text { total aktiva }} \times 100 \% \\
& \mathrm{BOPO}=\frac{\text { biaya operasional }}{\text { pendapatan operasional }} \times 100 \% \\
& \mathrm{NPM}=\frac{\text { laba bersih }}{\text { pendapatan operasional }} \times 100 \%
\end{aligned}
$$

4. Liquidity (likuiditas), yaitu jumlah kewajiban bersih call money terhadap aktiva lancar dan rasio antara kredit terhadap dana yang diterima oleh bank.

$$
\mathrm{LDR}=\frac{\text { kredit }}{\text { dana pihak ketiga }} \times 100 \%
$$

Perhitungan analisis CAMELS untuk aspek manajemen dan aspek sensitivitas dalam penelitian ini tidak dilakukan karena data yang diperlukan tidak dapat diperoleh. Datadata yang diperlukan tersebut tidak tercantum dalam laporan keuangan perusahaan yang dipublikasikan sehingga tidak dapat diperoleh.

Alat analisis korelasi digunakan untuk mengetahui apakah ada hubungan yang signifikan antara efisiensi perbankan syariah yang diperoleh dengan perhitungan DEA dengan kinerja perbankan yang dihitung dengan menggunakan analisis CAMELS. Teknik korelasi yang digunakan adalah teknik korelasi moment tangkar (product moment) dengan rumus sebagai berikut ini.

$$
r_{x y}=\sqrt{\frac{N \Sigma X Y-(\Sigma X)(\Sigma Y)}{\left\{N^{2}-(\Sigma X)^{2}\right\}\left\{N \Sigma Y^{2}-(\Sigma Y)^{2}\right\}}}
$$

Di mana:

$\mathrm{r}_{\mathrm{xy}}$ : Korelasi moment tangkar (product moment)

$\mathrm{N} \quad$ : Cacah subyek uji

$\Sigma \mathrm{X}$ : Sigma/jumlah X (rasio CAMELS)

$\Sigma X^{2} \quad$ : Sigma/jumlah $X$ kuadrat

$\Sigma Y \quad$ : Sigma/jumlah Y (Nilai DEA)

$\Sigma Y^{2}$ : Sigma/jumlah Y dikuadratkan

$\Sigma X Y$ : Sigma tangkar

Setelah korelasi dilakukan, maka langkah selanjutnya adalah menguji taraf signifikansi koefisien korelasi yang telah dihitung.

\section{Hasil Penelitian dan Pembahasan}

Berdasarkan hasil perhitungan untuk total kredit yang diberikan (total loan) diperoleh nilai maksimal total kredit yang diberikan oleh kesepuluh bank syariah sebesar Rp 52,259 milyar dengan nilai minimal sebesar Rp 6,354 milyar. Adapun rata-rata kredit yang diberikan setiap tahunnya oleh kesepuluh bank syariah adalah sebesar Rp 10,456 milyar per tahun.

Hasil analisis deskriptif untuk nilai investasi pada surat-surat berharga menunjukkan bahwa nilai maksimal investasi pada surat-surat berharga oleh kesepuluh bank syariah sebesar Rp 16,619 milyar dengan nilai minimal sebesar Rp 7,256 milyar. Adapun ratarata investasi pada surat-surat berharga setiap tahunnya oleh kesepuluh bank syariah adalah sebesar Rp1,403 milyar per tahun.

Hasil analisis deskriptif untuk nilai total deposit menunjukkan bahwa nilai maksimal total deposit oleh kesepuluh bank syariah sebesar Rp 28,609 milyar dengan nilai minimal sebesar Rp 79,835 juta. Adapun ratarata total deposit setiap tahunnya oleh kesepuluh bank syariah adalah sebesar Rp 6,064 milyar per tahun.

Biaya tenaga kerja dalam penelitian ini juga dimasukkan sebagai variabel input dalam analisis DEA. Hasil analisis deskriptif untuk biaya tenaga kerja menunjukkan bahwa nilai maksimal biaya tenaga kerja oleh kesepuluh bank syariah sebesar $\mathrm{Rp} 2,531$ dengan nilai minimal sebesar Rp 7,265 milyar. Adapun rata-rata biaya tenaga kerja setiap tahunnya oleh kesepuluh bank syariah adalah sebesar Rp722,341 milyar per tahun. 
Tabel 1 Statistik Deskriptif Variabel Penelitian

\begin{tabular}{lrrrr}
\multicolumn{1}{c}{ Variabel } & \multicolumn{1}{c}{ Minimal } & \multicolumn{1}{c}{ Maksimal } & \multicolumn{1}{c}{ Rata-Rata } & \multicolumn{1}{c}{ Deviasi Standar } \\
\hline Total Loan (Jutaan Rp) & $6.345,42$ & $52.258 .880,00$ & $10.456 .026,50$ & $16.674 .599,66$ \\
\hline Investment (Jutaan Rp) & $7.256,22$ & $6.619 .301,00$ & $1.403 .086,09$ & $2.124 .532,19$ \\
\hline Total Deposit (Jutaan Rp) & $79.835,36$ & $28.608 .526,00$ & $6.063 .513,70$ & $8.880 .109,92$ \\
\hline Labor (Jutaan Rp) & $7.265,97$ & $2.530 .575,63$ & $722.341,26$ & $879.189,69$ \\
\hline Total Assets (Jutaan Rp) & $103.445,96$ & $103.190 .823,00$ & $23.935 .236,99$ & $34.993 .498,52$ \\
\hline Efisiensi (DEA) & 0,03 & 1,00 & 0,73 & 0,34 \\
\hline CAR $(\%)$ & 10,73 & 25,72 & 14,08 & 4,51 \\
\hline KAP $(\%)$ & 1,28 & 3,19 & 2,35 & 0,78 \\
\hline NPM $(\%)$ & 3,40 & 15,78 & 7,50 & 4,07 \\
\hline ROA (\%) & $-0,57$ & 2,26 & 1,20 & 0,93 \\
\hline BOPO $(\%)$ & 75,14 & 103,75 & 92,77 & 8,25 \\
\hline LDR $(\%)$ & 75,26 & 104,98 & 91,69 & 10,37 \\
\hline
\end{tabular}

Tabel 2. Hasil Analisis DEA

\begin{tabular}{lrrr}
\hline \multicolumn{1}{c}{ Nama Bank } & Input (Jutaan Rp) & Output (Jutaan Rp) & \multicolumn{1}{c}{ Efisiensi } \\
\hline Bukopin Syariah & $22.083,1804$ & $11.861 .364,77$ & 1,000 \\
\hline BNI Syariah & 14.525 .725 & 25.585 .13 & 1,000 \\
\hline Muamalat & $26.279 .002,81$ & $78.759 .979,29$ & 1,000 \\
\hline Mandiri Syariah & 58.878 .181 & 133.311 .549 & 0,739 \\
\hline Mega Syariah & 12.041 .908 & 28.295 .559 & 0,867 \\
\hline BRI Syariah & 6.335 .676 & 27.536 .659 & 0,275 \\
\hline Danamon Syariah & $231.650,747$ & $619.248,208$ & 1,000 \\
\hline Niaga Syariah & $22.993,648$ & $765.091,507$ & 0,031 \\
\hline Permata Syariah & $178.207,358$ & $412.408,443$ & 0,641 \\
\hline BTN Syariah & $75.698,137$ & $190.547,285$ & 0,705 \\
\hline Rata-Rata & $11.859 .112,59$ & $30.721 .091,95$ & 0,726 \\
\hline
\end{tabular}

Nilai maksimal total aktiva oleh kesepuluh bank syariah sebesar Rp 103,190 milyar dengan nilai minimal sebesar Rp 103,445 milyar. Adapun rata-rata biaya tenaga kerja setiap tahunnya oleh kesepuluh bank syariah adalah sebesar Rp23,935 milyar per tahun.

Dalam pembahasan yang berkaitan dengan pengukuran efisiensi bank syariah digunakan alat bantu DEA untuk menganalisis faktor-faktor internal yang menyebabkan sebuah bank syariah efisien atau kurang efisien. Adapun urut-urutan analisis dengan menggunakan DEA adalah sebagai berikut:

1. menentukan variabel input (total credit yang diberikan (loan) dan investasi pada surat-surat berharga) dan output (total deposit, biaya tenaga kerja (labor), dan total assets;

2. menjalankan program DEAP;

3. memasukkan data melalui program DEAP, yaitu data-data input dan output yaitu dari tahun 2009 sampai dengan tahun 2011 pada 10 bank syariah yang diteliti;

4. menentukan cara perhitungan struktur bo- bot yang terdiri dari constant return to scale (CRS), banker, chames and cooper (BCC) atau variable returns to scale (VRS); 5. menjalankan perhitungan dengan program aplikasi DEAP;

6. menampilkan output hasil perhitungan; dan

7. menganalisis data hasil perhitungan dan menarik kesimpulan.

Dari hasil perhitungan yang dilakukan selama periode penelitian, diperoleh hasil bahwa 10 bank syariah menunjukkan kinerja yang relatif beragam dengan rasio kinerja dalam efisiensi mulai dari 3,1\% sampai $100 \%$. Adapun rata-rata efisiensi selama periode tiga tahun pada kesepuluh bank yang diteliti mencapai $83 \%$.

Berdasarkan Tabel 2, ada empat bank syariah yang menunjukkan tingkat efisiensi sebesar 100\%, yaitu Bank Bukopin Syariah, Bank BNI Syariah, Bank Muamalat, dan Bank Danamon Syariah. Enam bank syariah lainnya, yaitu Bank Mandiri Syariah, Bank Mega Syariah, Bank BRI Syariah, Bank Niaga Syariah, 
Bank Permata Syariah dan Bank BTN Syariah menunjukkan nilai efisiensi kurang dari $100 \%$ dengan kisaran efisiensi antara 3,1\%-86,7\%. Hasil ini bahwa tidak seluruh bank yang diteliti menunjukkan bank syariah yang efisien.

Apabila dilihat dari perkembangan tiaptiap tahunnya, menunjukkan adanya variasi dalam hal tingkat efisiensi bank dari tahun ke tahun, terutama pada periode penelitian, yaitu dari tahun 2009 sampai dengan tahun 2011. Tabel berikut ini menunjukkan perkembangan rasio efisiensi bank syariah dari tahun 2009 sampai dengan tahun 2011.

Tabel 3. Rasio Efisiensi Bank Syariah

\begin{tabular}{lccc}
\hline \multicolumn{1}{c}{ Nama Bank } & 2009 & 2010 & 2011 \\
\hline Bukopin Syariah & 0,004 & 0,020 & 0,065 \\
\hline BNI Syariah & 1,000 & 1,000 & 1,000 \\
\hline Muamalat & 1,000 & 0,870 & 0,945 \\
\hline Mandiri Syariah & 1,000 & 1,000 & 1,000 \\
\hline Mega Syariah & 1,000 & 1,000 & 1,000 \\
\hline BRI Syariah & 1,000 & 0,388 & 0,299 \\
\hline Danamon Syariah & 0,759 & 0,915 & 0,789 \\
\hline Niaga Syariah & 0,237 & 0,195 & 0,967 \\
\hline Permata Syariah & 0,992 & 1,000 & 1,000 \\
\hline BTN Syariah & 1,000 & 0,955 & 0,843 \\
\hline Rata-Rata & 0,799 & 0,734 & 0,791 \\
\hline
\end{tabular}

Tabel 3 memberi gambaran tentang hasil pengukuran rasio kinerja dari masing-masing bank syariah yang ada, dan selama periode penelitian terlihat bahwa untuk Bank syariah kinerja yang konstan dengan tingkat pencapaian tingkat efisiensi $100 \%$ ada empat bank syariah yaitu Bank Bukopin Syariah, Bank Muamalat, Bank Mega Syariah, dan Bank Permata Syariah. Untuk enam bank syariah lainnya menunjukkan tingkat efisiensi yang bervariasi dari tahun ke tahun.

Bank BNI Syariah menunjukkan tingkat efisiensi sebesar $83,6 \%$ pada tahun 2009 yang mengalami sedikit penurunan pada tahun 2010 menjadi 83,5\%. Namun demikian, pada tahun 2011, diperoleh nilai efisiensi sebesar $88,4 \%$ yang nilainya lebih tinggi dibandingkan dengan tahun 2009 dan tahun 2010.

Bank Mandiri Syariah menunjukkan fluktuasi dalam nilai efisiensi dari tahun 2009 sampai dengan tahun 2011. Pada tahun 2009, tingkat efisiensi Bank Mandiri Syariah mencapai $21,4 \%$ yang mengalami peningkatan pada tahun 2010 menjadi 44\%. Namun, pada tahun 2011 mengalami penurunan tingkat efisiensi menjadi $18 \%$.

Demikian juga dengan Bank BRI Syariah. Bank BRI Syariah menunjukkan fluktuasi dalam nilai efisiensi tahun 2009 - 2011. Pada tahun 2009, tingkat efisiensi Bank BRI Syariah mencapai $91,2 \%$ yang mengalami penurunan pada tahun 2010 menjadi $82,7 \%$. Namun, pada tahun 2011 mengalami peningkatan tingkat efisiensi menjadi 88,2\%.

Hal yang berbeda ditunjukkan oleh Bank Danamon Syariah yang menunjukkan adanya peningkatan terus-menerus dari tahun ke tahun yaitu tahun 2009-2011. Pada tahun 2009, efisiensi Bank Danamon Syariah menunjukkan sebesar $86,4 \%$ yang mengalami peningkatan pada tahun 2010 menjadi 93,2\%. Peningkatan ini berlanjut pada tahun 2011 di mana Bank Danamon Syariah mempunyai tingkat efisiensi mencapai $100 \%$.

Keadaan yang relatif sama dengan Bank Danamon Syariah dialami pula oleh Bank Niaga Syariah yang menunjukkan peningkatan terus-menerus dalam tingkat efisiensinya pada tahun 2009 - 2011. Pada tahun 2009, efisiensi Bank Niaga Syariah menunjukkan sebesar $25 \%$ yang mengalami peningkatan pada tahun 2010 menjadi 26,2\%. Peningkatan ini berlanjut pada tahun 2011 di mana Bank Niaga Syariah mempunyai tingkat efisiensi mencapai $67,3 \%$.

Bank BTN Syariah menunjukkan tingkat efisiensi yang relatif menurun dari tahun ke tahun. Pada tahun 2009, tingkat efisiensi Bank BTN Syariah mencapai $100 \%$ yang mengalami penurunan pada tahun 2010 menjadi hanya $95,5 \%$. Tingkat efisiensi yang sama dicapai pada tahun 2011.

Secara rata-rata, dari sepuluh bank syariah yang diteliti, menunjukkan adanya peningkatan pada tahun 2009 - 2011. Pada tahun 2009, rata-rata efisiensi sepuluh bank syariah yang diteliti mencapai $80,8 \%$. Tingkat efisiensi rata-rata ini mengalami peningkatan pada tahun 2010 menjadi $82,5 \%$ dan terus mengalami peningkatan pada tahun 2011 menjadi $85,7 \%$.

Analisis CAMELS dalam penelitian ini menggunakan enam rasio keuangan untuk perbankan syariah. Hasil analisis rasio CAMEL dapat dilihat pada Tabel 4 sebagai berikut ini. 
Tabel 4. Hasil Analisis Rasio CAMEL

\begin{tabular}{lrrrrrr}
\hline \multicolumn{1}{c}{ Nama Bank } & CAR $(\%)$ & KAP $(\%)$ & NPM $(\%)$ & ROA $(\%)$ & BOPO $(\%)$ & LDR (\%) \\
\hline Bukopin Syariah & 13,29 & 2,93 & 3,40 & 0,44 & 94,99 & 94,55 \\
\hline BNI Syariah & 25,72 & 1,58 & 6,25 & $-0,57$ & 103,75 & 75,26 \\
\hline Muamalat & 12,12 & 2,97 & 5,13 & 1,11 & 89,47 & 87,51 \\
\hline Mandiri Syariah & 10,76 & 1,28 & 6,39 & 2,21 & 86,70 & 82,57 \\
\hline Mega Syariah & 12,04 & 2,88 & 14,07 & 1,90 & 88,03 & 80,88 \\
\hline BRI Syariah & 17,47 & 1,78 & 7,43 & 3,60 & 98,61 & 102,45 \\
\hline Danamon Syariah & 13,41 & 3,19 & 5,26 & 1,23 & 99,92 & 104,04 \\
\hline Niaga Syariah & 12,33 & 3,19 & 15,78 & 2,07 & 97,20 & 104,04 \\
\hline Permata Syariah & 10,73 & 1,34 & 5,40 & 2,26 & 93,90 & 88,69 \\
\hline BTN Syariah & 12,89 & 2,38 & 5,89 & 0,99 & 75,14 & 95,96 \\
\hline Rata-Rata & 14,08 & 2,35 & 7,50 & 1,20 & 92,77 & 91,69 \\
\hline
\end{tabular}

Tabel 5 Korelasi Hasil CAMEL dengan Efisiensi DEA

\begin{tabular}{lccc}
\hline \multicolumn{1}{c}{ Rasio } & Korelasi dengan Efisiensi DEA & Signifikasi & Keterangan \\
\hline CAR & 0,141 & 0,698 & Tidak signifikan \\
\hline KAP & 0,071 & 0,846 & Tidak signifikan \\
\hline NPM & $-0,596$ & 0,069 & Tidak signifikan \\
\hline ROA & $-0,322$ & 0,364 & Tidak signifikan \\
\hline BOPO & $-0,061$ & 0,868 & Tidak signifikan \\
\hline LDR & $-0,515$ & 0,128 & Tidak signifikan \\
\hline
\end{tabular}

Pada analisis rasio modal dengan menggunakan CAR diperoleh hasil bahwa nilai CAR pada perbankan syariah relatif bervariasi. Bank Danamon Syariah menunjukkan tingkat rasio CAR yang paling tinggi yaitu mencapai 16,70 yang berarti bahwa $16,7 \%$ modal bank diperoleh dari aktiva atau modal perusahaan mencapai $16,70 \%$ dari aktiva total perusahaan. Nilai CAR terendah ada pada Bank Muamalat yaitu sebesar 6,81\%.

Analisis rasio aktiva dengan menggunakan rasio KAP menunjukkan bahwa nilai KAP berada pada kisaran 23,33\% - 41,33\%. Bank Bukopin Syariah mempunyai nilai KAP yang paling rendah sebesar $23,33 \%$, sedangkan Bank Mega Syariah menunjukkan nilai KAP tertinggi yaitu mencapai $41,33 \%$.

Rasio NPM menunjukkan nilai NPM berkisar antara 7,31 - 34,03. Rasio NPM terendah diperoleh oleh Bank Muamalat dengan nilai NPM sebesar 7,31. Nilai ini berarti bahwa $7,31 \%$ dari pendapatan operasional menjadi laba bersih perusahaan. Bank Mandiri Syariah mempunyai nilai NPM tertinggi, yaitu mencapai $34,03 \%$ yang menunjukkan bahwa 34,03\% dari pendapatan operasional menjadi laba bersih Bank Mandiri Syariah.

Perbandingan laba sebelum pajak dengan total aktiva yang ditunjukkan dari rasio
ROA menunjukkan bahwa Bank Muamalat mempunyai nilai rasio ROA sebesar 0,76 yang berarti bahwa laba sebelum pajak yang diperoleh oleh perusahaan mencapai $0,76 \%$ dari keseluruhan aktiva yang dimiliki oleh perusahaan. Nilai ROA tertinggi dicapai oleh Bank BRI Syariah yang menunjukkan nilai ROA sebesar 3,60 yang berarti bahwa laba sebelum pajak yang diperoleh oleh Bank BRI Syariah mencapai 3,60\% dari keseluruhan aktiva yang dimiliki oleh Bank BRI Syariah.

Rasio atau perbandingan biaya BOPO menunjukkan kisaran nilai antara 51,75 90,66. Nilai BOPO terendah yaitu sebesar 51,75 diperoleh oleh Bank Mandiri Syariah yang berarti bahwa dari keseluruhan pendapatan operasional Bank Mandiri Syariah, sebesar $51,75 \%$ adalah biaya operasional yang harus dikeluarkan. Adapun nilai BOPO tertinggi dicapai oleh Bank Muamalat yang menunjukkan nilai BOPO sebesar 90,66 yang berarti bahwa $90,66 \%$ pendapatan operasional Bank Muamalat digunakan untuk menutup biaya operasional Bank Muamalat.

Untuk mengetahui konsistensi hasil antara analisis efisiensi dengan menggunakan DEA dan analisis rasio CAMEL, maka digunakan pengujian korelasi antara hasil-hasil analisis DEA dengan CAMEL. Korelasi ini 
menunjukkan hubungan antara hasil DEA dan CAMEL guna mengetahui kesesuaian hasil kinerja DEA dan CAMEL..

Berdasarkan Tabel 5, rasio CAR menunjukkan nilai koefisien korelasi sebesar 0,141 dengan tingkat signifikansi sebesar 0,698. Ini berarti hubungan antara CAR dengan tingkat efisiensi adalah postiif yang menunjukkan peningkatan pada CAR akan mendorong peningkatan pada efisiensi DEA. Sebaliknya, penurunan pada CAR akan mendorong penurunan pada efisiensi hasil perhitungan DEA. Kondisi ini menunjukkan adanya kesesuaian antara hasil rasio CAR dengan efisiensi DEA karena seharusnya hubungan antara dua hasil tersebut adalah positif. Namun demikian, koefisien korelasi ini tidak signifikan secara statistik.

Rasio KAP dengan nilai efisiensi hasil perhitungan DEA menunjukkan nilai koefisien korelasi sebesar 0,071 dengan tingkat signifikansi sebesar 0,654. Ini berarti hubungan antara KAP dengan tingkat efisiensi adalah positif yang menunjukkan peningkatan pada KAP akan mendorong peningkatan pada efisiensi DEA. Sebaliknya, penurunan pada KAP akan mendorong penurunan pada efisiensi hasil perhitungan DEA. Kondisi ini menunjukkan adanya kesesuaian antara hasil rasio KAP dengan efisiensi DEA, namun demikian, koefisien korelasi ini tidak signifikan secara statistik.

Rasio NPM menunjukkan nilai koefisien korelasi sebesar -0,705 dengan tingkat signifikansi sebesar 0,846. Ini berarti hubungan antara NPM dengan tingkat efisiensi adalah negatif yang menunjukkan peningkatan pada NPM akan mendorong penurunan pada efisiensi hasil perhitungan DEA. Sebaliknya, penurunan pada NPM akan mendorong peningkatan pada efisiensi hasil perhitungan DEA. Kondisi ini menunjukkan tidak adanya kesesuaian antara hasil rasio NPM dengan efisiensi DEA karena seharusnya hubungan antara dua hasil tersebut adalah positif. Hasil analisis korelasi inipun signifikan secara statistik.

Rasio ROA menunjukkan nilai koefisien korelasi sebesar -0,322 dengan tingkat signifikansi sebesar 0,364. Ini berarti hubungan antara ROA dengan tingkat efisiensi adalah negatif yang menunjukkan peningkat- an pada ROA akan mendorong penurunan pada efisiensi DEA. Sebaliknya, penurunan pada ROA akan mendorong peningkatan pada efisiensi hasil perhitungan DEA. Kondisi ini menunjukkan tidak adanya kesesuaian antara hasil rasio ROA dengan efisiensi DEA karena seharusnya hubungan antara dua hasil tersebut adalah positif. Namun demikian, koefisien korelasi ini tidak signifikan secara statistik.

Rasio BOPO menunjukkan nilai koefisien korelasi sebesar $-0,061$ dengan tingkat signifikansi sebesar 0,868. Ini berarti hubungan antara BOPO dengan tingkat efisiensi adalah negatif yang menunjukkan peningkatan pada BOPO akan mendorong penurunan pada efisiensi DEA. Sebaliknya, penurunan pada BOPO akan mendorong peningkatan pada efisiensi hasil perhitungan DEA. Kondisi ini menunjukkan tidak adanya kesesuaian antara hasil rasio BOPO dengan efisiensi DEA, dan ini tidak didukung pula oleh nilai koefisien korelasi yang tidak signifikan secara statistik.

Rasio LDR menunjukkan nilai koefisien korelasi sebesar - 0,515 dengan tingkat signifikansi sebesar 0,128. Ini berarti hubungan antara LDR dengan tingkat efisiensi adalah negatif yang menunjukkan peningkatan pada LDR akan mendorong penurunan pada efisiensi DEA. Sebaliknya, penurunan pada LDR akan mendorong peningkatan pada efisiensi hasil perhitungan DEA. Kondisi ini menunjukkan adanya kesesuaian antara hasil rasio LDR dengan efisiensi DEA. Namun demikian, koefisien korelasi ini tidak signifikan secara statistik.

Rasio BOPO memberikan hasil yang tidak sejalan dengan analisis DEA karena arah hubungan (negatif) dan tidak signifikan secara statistik. Rasio lainnya pada analisis CAMEL tidak menunjukkan adanya kesesuaian dengan hasil-hasil pada analisis DEA karena tingkat signifikansi koefisien korelasi menunjukkan nilai yang tidak signifikan secara statistik.

\section{Kesimpulan}

Berdasarkan hasil analisis data dan pembahasan, maka dapat disimpulkan beberapa hal sebagai berikut ini. 
1. Hasil analisis DEA menunjukkan bahwa ada lima bank syariah yang menunjukkan nilai efisiensi mencapai $100 \%$ atau berada dalam taraf efisien, yaitu Bank Bank Bukopin Syariah, Bank Muamalat, Bank Mega Syariah, Bank Danamon Syariah, dan Bank Permata Syariah. Adapun lima bank syariah lainnya, yaitu Bank Danamon Syariah, Bank Mega Syariah, Bank Mandiri Syariah, Bank BTN Syariah, dan Bank Muamalat menunjukkan nilai efisiensi kurang dari $100 \%$ atau dapat dikatakan dalam kategori kurang efisien.

2. Dalam analisis rasio CAMELS menunjukkan bahwa bank-bank syariah dalam kondisi rasio keuangan yang baik karena dari rasio keuangan untuk faktor permodalan, aktiva, rentabilitas, dan likuiditas semuanya menunjukkan bahwa bank-bank syariah yang diteliti dalam kondisi yang bagus atau sehat. Namun demikian, nilai rasio menunjukkan fluktuasi dari tahun ke tahun selama periode penelitian.

3. Analisis korelasi antara hasil analisis CAMELS dengan DEA menunjukkan hanya rasio BOPO yang memberikan hasil yang sejalan dengan analisis DEA karena arah hubungan (positif) dan signifikan secara statistik. Rasio lainnya pada analisis CAMELS tidak menunjukkan adanya kesesuaian dengan hasil-hasil pada analisis DEA karena tingkat signifikansi koefisien korelasi menunjukkan nilai yang tidak signifikan secara statistik.

\section{DAFTAR PUSTAKA}

Kasmir, 2000, Manajemen Perbankan, Edisi 1, Rajagrafindo Persada, Jakarta.

Komaryatin Nurul, 2006, "Analisis Efisiensi Teknis Industri BPR di Eks. Karisidenan Pati", Tesis, Universitas Diponegoro, Semarang.
Mahi, Raksasa, 2000. "Prospek Desentralisasi di Indonesia Ditinjau dari Segi Pemerataan antar Daerah dan Peningkatan Efisiensi", Analisis CSIS, Vol. XXIX, No. 1, hal. 54-56.

Mulyadi, 2010, Sistem Akuntansi, Edisi ke-3, Cetakan ke-5, Penerbit Salemba Empat, Jakarta.

Nazir Moh., 1999, Metode Penelitian, Cetakan Ketiga, Ghalia, Jakarta.

Ozcan Yasar A., 2008, Health Care Benchmarking and Performance Evaluation, Springer, New York.

Pause, 2000. Pengukuran Efisiensi: Data Envelopment Analysis (DEA) Pelatihan Metodologi Penelitian Empiris Metode Kuantitatif Ekonomi dan Bisnis, PAU Studi Ekonomi Universitas Gadjah Mada, Yogyakarta.

Purwantoro N.R., 2003, "Penerapan Data Envelopment Analysis (DEA) dalam kasus Pemilihan Produk Inkjet Personal Printer", Jurnal Usahawan, Vol 32 No. 10.

Ramanathan R., 2003, An Introduction to Data Envelopment Analysis: A Tool for Performance Measurement, Sage Publications, New Delhi:

Republika 25/6/2003.

Silkman Richard H., 1986, Measuring Efficiency: An Assesment of Data Envelopment Analysis. Jossey-Bass Inc. Publishers.

Singarimbun Masri, 1995, Metode Penelitian Survei, LP3S, Jakarta.

Sufian Fadzlan dan Madjid Muhd-Zulkhibri Abdul, 2008, "Bank Ownership, Characteristics, and Performance: A Comparative Analysis of Domestic and Foreign Islamic Banks in Malaysia", KAU: Islamic Economy, Vol. 21, No. 2, hal. 3-37. 